\title{
Fødevaresikkerhed over nettet \\ - en udfordring der blev løst
}

\section{Leon Brimer}

Lektor, PhD., Doktor pharm.

Det Biovidenskabelige fakultet (LIFE), Institut for Veterinær Sygdomsbiologi, Københavns

Universitet.

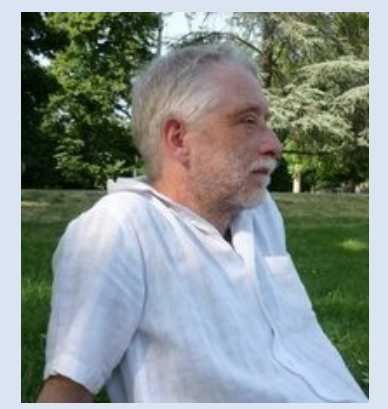

Leon Brimer, M.Sc., Ph.D. and D.Sc. (pharm), er lektor i farmakologi, toksikologi og fødevaresikkerhed ved Institut for Veterinær Sygdomsbiologi/Biomedicin, Det Biovidenskabelige Fakultet, Københavns Universitet. Medlem af the Linnean Society, London og indbudt medlem af Danmarks Naturvidenskabelige Akademi. Har tidligere været knyttet til Dansk Bilharzioselaboratorium og det Farmaceitiske Fakultet ved Københavns Universitet. 


\section{Abstract}

Fødevarer produceres verden over. I dag fragtes de verden rundt i et stadigt stigende omfang. I denne globaliserede virkelighed bør uddannelse i kemisk- og mikrobiel fødevaresikkerhed og risikovurdering være interdisciplinær og international i alle aspekter.

Med baggrund i et eksisterende kursus i kemisk fødevaresikkerhed for fødevarestuderende, som år for år fik flere studerende fra udlandet (Europa, Asien, Afrika og Sydamerika), samt et grundkursus for veterinærstuderende i mikrobiologisk fødevaresikkerhed besluttede to undervisere at skabe noget nyt. Det blev til et kursus i risikovurdering, kemisk såvel som mikrobiologisk, for fødevare- og veterinærstuderende i blandet flok.

Efter et par år skulle der nye udfordringer til. Vi gik i gang med at udvikle et $100 \%$ online-kursus i kemisk og mikrobiologisk fødevaresikkerhed. Det ni uger lange kursus (7,5 ECTS) har nu været afviklet for første gang med 12 tilmeldte, hvoraf de 11 gennemførte. De studerende repræsenterede Danmark, Sverige, Polen, Belgien, Frankrig og Portugal.

Kurset udvikledes med udgangspunkt i professor Gilly Salmon's (University of Leicester) 5-trins model for e-læring; som denne løbende er blevet praktisk videreudviklet ved Det Biovidenskabelige Fakultet, KU, af ITlearning Centers e-læringskonsulenter. I praksis byggede læringen i det færdigudviklede kursus på såkaldte "e-tivities" med skrevne faglige onlinediskussioner mellem hhv. studerende og studerende-undervisere. Eksamen gennemførtes som videomøde mellem de to undervisere og den enkelte studerende under anvendelse af Adobe Connect software.

Vi erfarede, at samspillet mellem de forskellige fødevarekulturer kunne bringes til at berige kurset når e-tivities formuleredes således, at den enkelte studerende tog udgangspunkt i en blanding af uddannelsesbaggrund og hjemlig mad-kulturel viden. Praktiske erfaringer blev høstet specielt vedrørende afvikling af "videomøde-eksamen", som nærmere redegjort for i artiklen.

\section{At spise er blevet et internationalt anliggende}

Fødevarer produceres over hele verden; sådan har det altid været. Men i dag fragtes de også verden rundt $i$ et stadigt stigende omfang. I Danmark spiser vi den ene dag grapefrugt fra Sydafrika, den næste opdrættede laks fra Norge, den tredje hindbær dyrket i Polen og endelig den fjerde rød quinoa fra Sydamerika. Vi skal ikke mange år tilbage for at finde udbrud af den såkaldte Roskildesyge på grund af infektion med norovirus fra hindbær importeret fra Polen, og vi kan regelmæssigt læse, at fødevarestyrelsen trækker et produkt tilbage fra hylderne, f.eks. et fiskekonserves produkt med for højt indhold af giftstoffet histamin. Fødevare (u)sikkerhed er med 
andre ord blevet international og rummer mikrobiologiske såvel som kemiske aspekter.

I denne globaliserede virkelighed bør den på højeste niveau (universitetsniveau) udbudte uddannelse i kemisk- og mikrobiel fødevaresikkerhed og risikovurdering være interdisciplinær og international i alle dens aspekter. Det vil sige, at der bør være kurser hvor studerende med forskellig uddannelsesmæssig geografisk/etnisk baggrund møder hinanden med mulighed for at udfordre og inspirere hinanden og underviserne til at opnå den bredest mulige forståelse af problemerne og deres mulige løsning.

\section{Fødevaresikkerhed som universitetsdisciplin}

På det Biovidenskabelige Fakultet, KU (tidligere Landbohøjskolen), har vi i årtier tilbudt en række uddannelser, som giver kompetencer inden for hver deres del af vores fødevare-produktionskæde. Således agronom med speciale i enten plante- eller husdyrproduktion, hortonom med viden om produktion af frugt og grønt, dyrlæge (veterinær) med viden om produktionsdyrs sundhed samt om kødkontrol på slagterier for sikring af sunde animalske produkter, fødevarevidenskab med viden om hvordan forarbejdning af råvarer påvirker fødevarernes kvalitet og endelig humanog klinisk human ernæring.

En god del af disse uddannelser, dog først og fremmest kandidatgraderne i fødevarevidenskab og veterinærmedicin, indeholder obligatoriske eller valgfri kurser vedrørende fødevaresikkerhed "fra jord til bord".

Som det vil være de fleste af LOM's læsere bekendt, er der i løbet af det seneste årti sket en kraftig udvikling i antallet af udenlandske studerende, som tager et par kurser eller en hel M.Sc. ved et dansk universitet. Denne tendens har vi også set ved det Biovidenskabelige Fakultet, bl.a. med den konsekvens at vores grundkursus i kemisk fødevaresikkerhed "Chemical Food Safety" (7,5 ECTS), som i en del år har været afviklet på engelsk, har modtaget et stadig stigende antal udenlandske (fysisk tilstedeværende) studerende. Kurset tages hovedsagelig af fødevarestuderende, af hvilke godt halvdelen nu er udlændinge - oftest repræsenterende tre eller fire verdensdele.

For veterinærmedicins vedkommende stiller situationen sig lidt anderledes, idet de næsten 200 årligt optagne studerende hovedsagelig er danske med et islæt af svenske og norske statsborgere. I modsætning til hvad der er tilfældet for de øvrige studieretninger ved Biovidenskabelige Fakultet, foregår langt størsteparten af undervisningen på veterinærstudiet også på dansk. Studiet indeholder således en række grundkurser i bl.a. bakteriologi og fødevaremikrobiologi som afvikles dansk. 


\section{Første skridt mod at samle studerende på tværs af studier og sammensmelte beslægtede}

\section{fag}

For ca. fire år siden stak den kursusansvarlige for det allerede nævnte kursus "Chemical Food Safety" (Leon Brimer) hhv. kurset i mikrobiel fødevaresikkerhed for veterinær studerende (professor Hanne Ingmer) hovederne sammen og besluttede at udvikle er valgfrit fag-integreret overbygningskursus henvendt til såvel fødevarestuderende som veterinærstuderende. Kurset skulle afholdes på engelsk.

Resultatet blev et videregående kursus med elementer af kemisk- såvel som mikrobiel fødevaresikkerhed og med hovedvægten på hhv. teoretisk og praktisk (relateret til forgiftningsudbrud) risikovurdering og kildeeftersporing.

Kurset blev en succes i den forstand, at det i de følgende tre år fik deltagelse af en blanding af fødevare- og veterinærstuderende (som oprindelig ønsket), og at der hvert år var en betragtelig procentvis deltagelse af fødevarestuderende fra andre lande; herunder andre verdensdele. Det blev også en succes i den forstand, at vi hvert år med tilfredshed kunne konstatere, at deltagerne næsten samstemmende udtrykte glæde ved alle tre "integrationselementer", dvs. blandingen af studieretninger, fagintegrationen, og det faktum at flere landes fødevarekultur var repræsenteret.

\section{Nu var det tid at gå online}

Da IT- og Telestyrelsen i foråret 2008 offentliggjorde opslag om støttemuligheder til udvikling af fjernundervisning på universitetsniveau så Hanne Ingmer og jeg en oplagt mulighed for at gå skridtet videre; at skabe et fagintegreret, engelsksproget og $100 \%$ webbaseret kursus. Et kursus med potentiel mulighed for deltagelse af alle kvalificerede studerende uanset hvor disse måtte befinde sig og på hvilke tidspunkter $\mathrm{i}$ løbet af dagen og ugen, de måtte have mulighed for at være studieaktive. Der kunne være tale om universitetsstuderende såvel som ansatte ved fødevarevirksomheder eller kontrolinstanser for fødevaresektoren, eller evt. om selvstændige konsulenter. Vi udformede derfor en ansøgning om støtte til udviklingsprojektet "Chemical and Microbiological Food Safety an advanced online course". 


\section{Arbejdsgruppen og valg af e-lærings model.}

\section{Arbejdsgruppen}

Ud over de to allerede nævnte fagundervisere blev endnu to mikrobiologer og en toksikolog/kemisk fødevaresikkerhedskyndig inddraget $\mathrm{i}$ arbejdsgruppen, som skulle tage sig af den praktiske udvikling af de planlagte studiematerialer. Men et er at være fagundervisere i hhv. kemiskog mikrobiologisk fødevaresikkerhed, noget andet at vide, hvordan man kommunikerer med og måske endnu vigtigere holder gejsten oppe hos studerende, som man aldrig møder ansigt til ansigt. Så vi aftalte et samarbejde med fakultetets IT-learning Center, idet centrets leder Gitte Preisler kom til at indgå i den central projektstyringsgruppe, samtidig med at e-læringskonsulent Anita Monty blev tilknyttet projektet som fast elæringskonsulent og medlem af arbejdsgruppen. Også fakultetets bibliotek blev kontaktet, og man enedes om også at tilknytte en fagbibliotekar til arbejdsgruppen. Denne udviklede sammen med denne artikels forfatter en e-tivity om litteratursøgning med fokus på fødevaresikkerhed. Her fik den studerende ved egen aktiv søgning i bibliotekets online-databaser testet sin effektivitet $\mathrm{i}$ at finde det rette - og kun det.

På trods af den efterhånden ret omfattende arbejdsgruppe, blev det allerede ved udarbejdelsen af ansøgningen vurderet, at specielt de to hovedfaglærere ikke ville have tid nok til rådighed til at detailudforme og producere alt det nødvendige materiale. Det blev derfor planlagt at ansætte en projektmedarbejder med faglig baggrund for at indgå i denne rolle på baggrund af oplæg fra hovedfaglærerne. Efter tildeling af støtte ansatte vi den nyuddannede cand. med. vet. Karina Barbara Andersen i denne funktion.

\section{E-læeringsmodel}

Kurset er blevet udviklet med udgangspunkt i professor ved University of Leicester Gilly Salmon's 5-trins model for undervisning på nettet (Salmon, 2003; se også se http://www.atimod.com/e-moderating/5stage.shtml), en model som er videreudviklet og praktisk eksemplificeret på Det Biovidenskabelige Fakultet gennem de seneste år. Denne udvikling har taget afsæt i fakultetets IT Learning Center, som har stået for undervisning og sidemandsoplæring af de undervisere, som er involveret i e-læring (ITfaciliteret undervisning); herunder også undervisere på det her omtalte kursus. IT Learning Center har under forløbet af tidligere kurser såvel som under udvikling og afholdelse af dette kursus foretaget en aktiv erfaringsopsamling. 


\section{Kurset}

I praksis betyder valget af e-læringsmodel, at kurset er opbygget i et antal e-moduler som vist i Figur 1: Kursets overordnede struktur.

\section{Part I: Chemical Food Safety}

\begin{tabular}{|l|l|}
\hline $\begin{array}{l}\text { Week 16 } \\
\text { (start }\end{array}$ & $\begin{array}{l}\text { E-module 1: Welcome and Introduction to Food and Food } \\
\text { 19.04.2010) }\end{array}$
\end{tabular}

\begin{tabular}{|l|l|}
\hline Week & E-module 2: From toxicology to chemical food safety \\
17 &
\end{tabular}
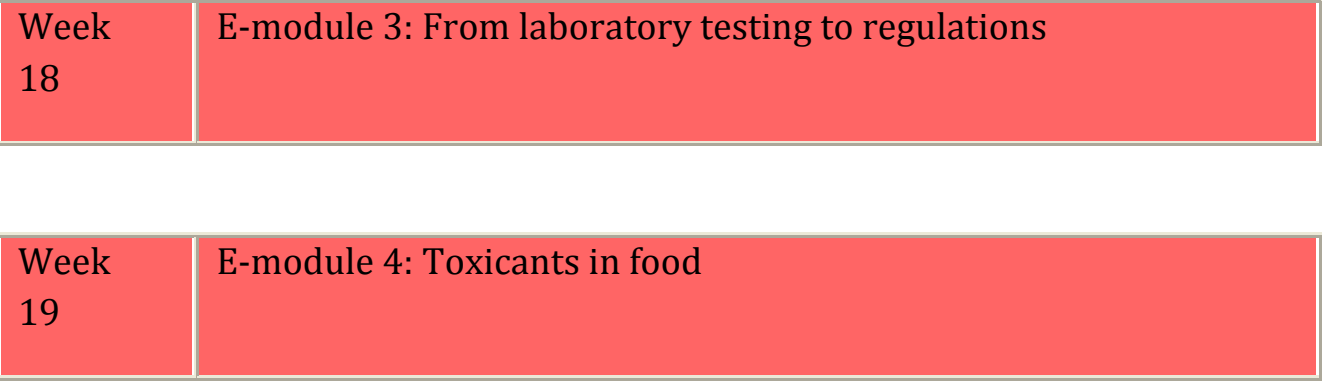

\section{Part II: Microbiological Food Safety}

\begin{tabular}{l|l}
\hline Week & E-module 5: Introduction to pathogens and processes
\end{tabular}

20

\begin{tabular}{l|l} 
Week & E-module 6: Outbreak investigation and detection methods
\end{tabular}

21

\begin{tabular}{|l|l|}
\hline Week & E-module 7: Typing \\
22 & \\
\hline
\end{tabular}

\begin{tabular}{l|l} 
Week & E-module 8: Control in real life \\
23 &
\end{tabular}




\title{
Examination and Evaluation
}

\begin{tabular}{|l} 
Week \\
24 \\
\hline Week \\
25
\end{tabular}

\author{
Examination
}

Figur 1.

Hvert e-modul består af et antal e-lessons som eksemplificeret med strukturen af modul 3. Se Figur 2: Overordnet indholds strukturering af modul 3.

\section{Overview of the E-lessons in module 3}

\section{Study guide to E-module 3}

E-lesson 3.1: Food safety regulations systems worldwide

E-lesson 3.2: Testing for toxicity in vivo animal studies

E-lesson 3.3: Testing for toxicity in vitro studies

\section{E-lesson 3.4: GMO}

E-lesson 3.5: Risk assesment

Figur 2.

Som det ses af Figur 2, gives der foruden de enkelte e-lessons også (1) et indledende overblik over hele modulet og dets indhold samt (2) en såkaldt "study guide" for modulet. "Study guiden" er en meget kortfattet tekst med få operative råd til den studerende vedrørende netop dette modul, og hvorledes man bedst tilgår det. Dette er illustreret i Figur 3: "Study guide" for e-modul 3. 


\section{Study guide for E-module 3}

The E-lessons should be started as soon as possible and generally two- three posts to each discussion forum are required for passing the E-lesson.

In E-lesson 3.2 it may be an advantage for understanding of the video to read the background paper on testing for toxicity prior to watching the video in the spark on Brines testing.

In E-lesson 3.4 it is optional whether you prefer to read the chapter in the book or to read the three articles.

Figur 3.

Den enkelte e-lesson er udformet efter er skema med følgende elementer:

(1) Spark, (2) Objective, (3) Task, (4) Response, (5) Resources og (6) Start

+ Deadline. Et eksempel vises nedenfor i Figur 4: Struktur for e-lesson som

eksemplificeret med E-lesson 3.1.

\section{E-lesson 3.1: Food safety regulatory systems worldwide}

- Spark: It's regulated they say - but by whom? What about the food scandals in China (melamine in milk) 2008/09, in Spain (toxic food oil) 1981, in Belgium (dioxin in animal feed) 1991 etc., can I trust that the regulations make my life safer?

- Objective: To give an overall introduction to the history of food safety regulatory systems worldwide and the international institutions currently existing along with an introduction to toxicity testing.

- Task: Watch the PowerPoint presentation about international organisations. Go to the web home page of either WHO or FAO and find a notice (an article) about a chemical food safety issue/a story which currently (or recently) has been discussed/pointed to. Write a short notice where you in your own words describe the issue at least with respect to the following: the overall issue/problem, the geographical region for which it is/was relevant, the type of notice/article that you found, and the exact web address. Post your notice to the discussion forum.

- Response: Read the other contributions. Teacher summarizes. Read the teacher's summary and post a comment to this. Teacher answers the comments.

- Resources: WHO and FAO WebPages.

- Start + deadline: May $1^{\text {st }}$ to May $7^{\text {th }}$ first post should be no later than May $4^{\text {th }}$

Figur 4.

"Sparket" varierede mellem en tekst som vist ovenfor og en video, som de studerende skulle se. Ofte havde vi hentet én eller flere relevante "spark-videoer" fra YouTube.

"Task" varierede f.eks. mellem at komme med (1) diskussionsindlæg, (2) fremstille (udfylde) en PowerPoint, eller (3) besvare en multiple choice opgave. I hvert enkelt tilfælde på baggrund af studiet af et 
baggrundsmateriale (en/flere ressource(r)) som på sin side kunne bestå af:

a) et kapitel i den til kurset knyttede lærebog,

b) en af underviserne elektronisk udlagt original forskningsartikel,

c) en original forskningsartikel som den studerende selv skulle finde frem til på basis af nogle oplysninger/spørgsmål,

i) Som noget unikt var LIFE's bibliotek inddraget i kurset fra starten.

Biblioteksrepræsentanten havde udformet en række online-

vejledninger til bibliotekets databaser og kunne kontaktes af de studerende online. En enkelt e-lesson fokuserede specielt på at anvende en række forskellige litteraturdatabaser til en given søgning for herefter at lave en sammenlignende analyse vedrørende de forskellige resultater,

d) en "PowerPoint med speak" fremstillet til kurset og udlagt som ressource,

e) en undervisningsvideo fremstillet til kurset (5 hver a ca. 15-20 minutter),

f) oplysninger hentet af den studerende på internet-hjemmesider som f.eks. hjemmesiderne for FAO og WHO.

Som det fremgår af Figur 1 forløb kurset over ni uger (16-24). Organisationsmæssigt foregik undervisningen ved, at den faglærer, som var tilknyttet den enkelte e-lesson, startede opgaven ved at åbne diskussionsforum med et indlæg. Herefter kom de studerende med deres indlæg (et eller flere; evt (ofte) med svar/reaktioner på andre studerendes indlæg). Faglæreren fulgte diskussionerne og kommenterede løbende samt udformede en afsluttende kommentar. I praksis havde vi ansat en kursusudvikler, Karina Barbara Andersen, som under kursets afvikling fungerede som supplerende e-facilitator med vægten på de nødvendige organisatoriske og socialiserende indlæg.

\section{Hvem var de endelige deltagere og hvad med teknologien?}

Kursusudvikling, afprøvning af nogle moduler på få studerende fra et fysisk tilstedeværelseskursus, markedsføring og oplægning i det anvendte Learning Management System (LMS) løb fra d. 01.10.2008 til d. 15.04.2010 hvor kurset endelig løb af stablen med 12 deltagere. Se Figur 5: De studerendes karakteristika. 


\begin{tabular}{|c|c|}
\hline $\begin{array}{l}\text { Studieretning } \\
\text { i hjemland }\end{array}$ & Hjemland \\
\hline Agronomi & Frankrig \\
\hline Agronomi & Frankrig \\
\hline Agronomi/ & Belgien \\
\hline $\begin{array}{l}\text { Fødevare } \\
\text { videnskab }\end{array}$ & \\
\hline $\begin{array}{l}\text { Mejeri } \\
\text { videnskab }\end{array}$ & Danmark \\
\hline Bioteknologi & Polen \\
\hline Bioteknologi & Polen \\
\hline $\begin{array}{l}\text { Mejeri } \\
\text { videnskab }\end{array}$ & Danmark \\
\hline $\begin{array}{l}\text { Fødevare } \\
\text { videnskab }\end{array}$ & Sverige \\
\hline $\begin{array}{l}\text { Mejeri } \\
\text { videnskab }\end{array}$ & Danmark \\
\hline $\begin{array}{l}\text { Miljø } \\
\text { videnskab }\end{array}$ & Portugal \\
\hline Bioteknologi & Polen \\
\hline Bioteknologi & Polen \\
\hline
\end{tabular}

Figur 5.

Det var altså lykkedes at tiltrække studerende fra en lang række europæiske lande, studerende som samtidig repræsenterede en række forskellige - om end beslægtede - uddannelser inden for anvendt naturvidenskab. Målgruppen var nået.

Kurset afvikledes i KU's LMS, "Absalon", under anvendelse af speakede PowerPoint præsentationer (afviklet i "Adobe Presenter"), laboratoriumdemonstrationsvideoer originalt fremstillet til kurset (afviklet i Adobe Presenter), samt online-møder (og eksamen) mellem den enkelte studerende og underviseren (ved eksamen begge hovedundervisere) under 
anvendelse af "Adobe Connect" med både tovejs-lyd- og to-vejs billede forbindelse.

\section{Hvad fungerede og hvad ikke?}

Det var vores mål at få de studerende gradvis socialiseret gennem deltagelse i en række introducerende e-tivities med et langsomt stigende fagspecifikt indhold (modul 1). Modulet bestod af seks e-tivities med følgende titler: "Welcome", "The who, what and why"," You and food", "How does it work", "The gossip about food safety", og "The rules of the game". I "Who what and why" - modulet skulle den studerende fortælle om sine bevæggrunde til at deltage i kurset:

- Task: Go to the discussion forum and post a statement on why you chose the course. What does your interest in microbiological and chemical food safety involve? Use both of the videos in lesson 1.1 and 1.2 as an inspiration to get started. Response: Respond in a positive manner to two statements from fellow students preferably to the ones who have made different statements than you.

I "You and food" - modulet skulle den studerende fortælle om sin hjemlige madkultur og dens baggrund - herunder om denne evt. afspejler at den studerende tilhører en speciel overbevisning (vegetar etc.) eller religiøs/etnisk gruppe.

- Task: Watch the videos in the spark. Write a statement in the discussion forum that contains:

o Something about where you get your food from.

o What type of food it may be.

o What shopping possibilities do you have and which do you usually go to?

o Are there any food producing companies of any kind near your home?

o Which preparations of the food do you typically use and which has your food undergone when you purchase them?

o Do you or your family belong to a special group in the society and does your choice of food reflect this?

Den planlagte "fagspecifikke socialisering" syntes at fungere endog rigtig godt, bl.a. afspejlet i det faktum, at frafaldet var yderst begrænset.

In e-lesson 1.4 "How does it work?" var det vores mål at få den enkelte studerende til at arbejde sig igennem de forskellige funktionaliteter i det anvendte "Absalon". Vi skrev således:

Spark: It is always helpful to know how a system works and what actions to take next. 
Objective: Ability to navigate the course pages, understand the requirements for completing E-learning modules and taking the exam, and adjust settings for Absalon messages.

Desværre skrev vi også "hvis nogle problemer/spørgsmål så skriv til "Discussion forum". Resultatet af denne "løse" opgave form var, at vi ingen indlæg fik - og dermed intet indtryk af de studerendes aktivitet i denne elesson.

\section{Konklusion}

Elleve fuldførte ud af de tolv, der startede. Underviserne var generelt overraskede over det høje antal af diskussionsindlæg fra de studerendes i langt de fleste af kursets webdiskussioner, i gennemsnit ca. tre per studerende per e-lesson. Både når vi som undervisere ser på den løbende online-dialog og på eksamensresultaterne, vurderes de studerendes læring at være fuldt på højde med den kvalitet, som opnås ved konventionelle kurser - måske endog en smule bedre.

Teknisk blev alt blev bragt til at virke, om end der - på basis af problemer blev gjort en del erfaringer, specielt vedrørende afvikling af online-møder. Særligt tovejs-lydforbindelserne viste sig at kunne give anledning til problemer. Anvendelse af head-set viste sig at være ret essentielt. Det viste sig endvidere, at det ofte kan føre til problemer, at lydstyrke (samt lyd fra/til) ofte kan reguleres på flere niveauer hos hver af de deltagende parter. Der udarbejdedes derfor en "Sådan gør du" vejledning, som blev lagt elektronisk frem. Endelig besluttedes det, at man altid før et elektronisk møde skal have udvekslet telefonnumre, så de enkelte parter kan kontakte hinanden, hvis kontakt ikke skabes over web'en som aftalt.

Det har været sagt (Vrasida \& McIsaac, 1999) at:

- Online environments that rely heavily on text-based communication lack the visual and audible cues present in traditional face-to-face classrooms.

- As a result, communication that takes place in such environments has often been criticized as lacking in richness.

- We feel that it is in the hands of the instructor to create the feelings of the learning communities and social presence.

- Only good balance between the structure of the course and the online interactions can provide for an optimal learning experience”.

I det beskrevne kursus mener vi, at vi lykkedes med at skabe et godt studiesocialt miljø. Det kan dog ikke understreges nok, at det synes essentielt at have gennemført et eller flere videomøder med de studerende før en evt. videokonference-baseret eksamen. Dette sikrer ikke blot, at det tekniske fungerer, men også at undervisere og studerende føler sig trygge ved hinanden før denne skalsættende begivenhed. 


\section{Referencer}

Salmon, G. (2003). E-tivities: the key to active online learning (2nd ed.). London: Taylor and Francis.

Charalambos Vrasidas, C. \& McIsaac, M. S. (1999). Principles of Pedagogy and Evaluation for Web-Based Learning [Electronic Version]. Retrieved November 10, 2010, from

http://seamonkey.ed.asu.edu/ mcisaac/ICEM99/pedagogymss.html 